\title{
Combine Harvester: Small Machine Solves Big Rice Harvesting Problem of Bangladesh
}

\author{
Bidhan Chandra Nath* ${ }^{\circledR}$, Subrata Paul, Md Durrul Huda, Md Anwar Hossen, \\ MGK Bhuiyan, AKM Saiful Islam \\ Bangladesh Rice Research Institute, Gazipur, Bangladesh \\ Email: ^bidhanbrri@gmail.com, ^Bidhan.nath@usq.edu.au, engr.subrata_paul@hotmail.com, mdurrulh@hotmail.com, \\ ahossenbrri@gmail.com,kibria_1971@yahoo.com,akmsaiful68@yahoo.com
}

How to cite this paper: Nath, B.C., Paul, S., Huda, M.D., Hossen, M.A., Bhuiyan, MGK and Islam, AKM S. (2022) Combine Harvester: Small Machine Solves Big Rice Harvesting Problem of Bangladesh. Agricultural Sciences, 13, 201-220. https://doi.org/10.4236/as.2022.132015

Received: January 14, 2022

Accepted: February 13, 2022

Published: February 16, 2022

Copyright $\odot 2022$ by author(s) and Scientific Research Publishing Inc. This work is licensed under the Creative Commons Attribution International License (CC BY 4.0).

http://creativecommons.org/licenses/by/4.0/

\section{(c) (i) Open Access}

\begin{abstract}
Bangladesh, a country with $87 \%$ of rural households that depend on agriculture and rice dominated diets (70\%), engages the country's food security. Therefore, there is strong advocacy for a mechanized paddy harvesting system for food security in South Asia, mainly Bangladesh. Some harvesting machinery is available; however, the precise roles of a combine harvester during this process are little. This study attempts to understand the consequences of combining harvesters for paddy harvesting and compare them with hand harvesting. For comparison of field performance of combine harvester with traditional harvesting, the experiment was conducted at Gazipur District, Bangladesh, in 2016. Results showed that the labor required for harvesting unit area 283, 15 and 9.87 man-h.ha ${ }^{-1}$ for $\mathrm{T}_{1}$ (Sickle + Head carry + Beating + Kula), $\mathrm{T}_{2}$ (Reaper + Trolley carry + Close drum thresher + winnower), $\mathrm{T}_{3}$ (Combine harvester) system, respectively. Likewise, the harvesting costs were $1.84\left(\mathrm{~T}_{2}\right)$ and $2.5\left(\mathrm{~T}_{1}\right)$ times higher than the combine harvester $\left(\mathrm{T}_{3}\right)$. Also, the postharvest loss can be saved $1.84 \%$, to use combine harvester over manual harvesting of paddy. The above result revealed that the semimechanized and mechanized harvesting system is a time, labor and costsaving system; however, the manual reaping system is concerned with more postharvest losses (3.09\%). This study highlights the importance of combine harvester; however, further research is required in other places with large and mini-combine harvesters under diverse cropping areas and to test a combine harvester's detailed potentiality.
\end{abstract}

\section{Keywords}

Combine Harvester, Harvesting, Labor, Paddy, Postharvest Losses 


\section{Introduction}

The global population will reach 9.61 billion by 2050 and 11.2 billion in 2100 [1]. Consequently, the staple food consumption, comprising wheat, maize and rice is likely to increase vividly, especially in developing countries [2]. More than double food and production are required to ensure global food security [3]. This situation is challenged by expected pressure on global cropland availability. As a result, worldwide calls intensify production on available land sustainably (to keep natural land conservation, avoid biodiversity loss) [3]. These problems are acute in densely populated South Asian countries, including Bangladesh, which records a poor population living less than USD $1.90 \mathrm{day}^{-1}$ [4]. In Bangladesh, almost $38.85 \%$ of the population depended primarily on agriculture [5], and about $87 \%$ of rural households income depended on agriculture [6]. The country's agriculture sector also contributes approximately $13.68 \%$ of the country's gross domestic product (GDP) [6] and employs more than $45 \%$ of the total labor force [7]. To keep the food supply pace with the additional two million population added annually, Bangladesh will need to increase rice and wheat production by $0.4 \%$ and $2.17 \%$ per year, respectively [8]. Moreover, the most recent studies [9] [10] estimated that feeding 215.4 million people in 2050 will be required 44.6 million tons of cleaned rice, whereas annual land shrinkage is 0.08 million hectares due to non-agricultural activities.

In Bangladesh, rice is an important cereal crop for national food security and is estimated for $93 \%$ of all food produced [11]. Also, $70 \%$ of calorie intake is from rice [12]. [13] noted that "rice security" is synonymous with "food security" in Bangladesh, like many other rice-growing nations. Therefore, satisfactory rice production is the primary strategy to ensure Bangladesh food security [10]. Accordingly, the Government of Bangladesh has prioritized increasing the main cereal crop (rice), contributing to socio-economic development. Furthermore, Bangladesh's people called: rice is a political crop, because government stability depends on rice availability. The primary way to increase rice production is: 1) yield intensification, 2) yield gap minimization between the research field and farmer's level, and 3) postharvest loss reduction. Several research results noted that mechanical intervention is one of the best ways to decrease the yield gap, minimize the postharvest losses, increase the farmers' revenue [12] [14] [15].

Rice production depends on land cultivation, planting, intercultural care, harvesting and processing [16]. Among the crop production actions, harvesting is a decisive activity regardless of all crops, related to productivity and farmer's income [10]. Rice harvesting system belongs to cutting, transportation, threshing, cleaning and bagging (Figure 1). In developed countries, most of the harvesting action is done mechanically, but in developing countries, harvesting mechanization is partial due to lake of sustainable technology and machinery use knowledge gap (Figure 2). For example, in Bangladesh, 95\% of cutting is done manually (sickle), but $95 \%$ of threshing was completed by machine [17]. 


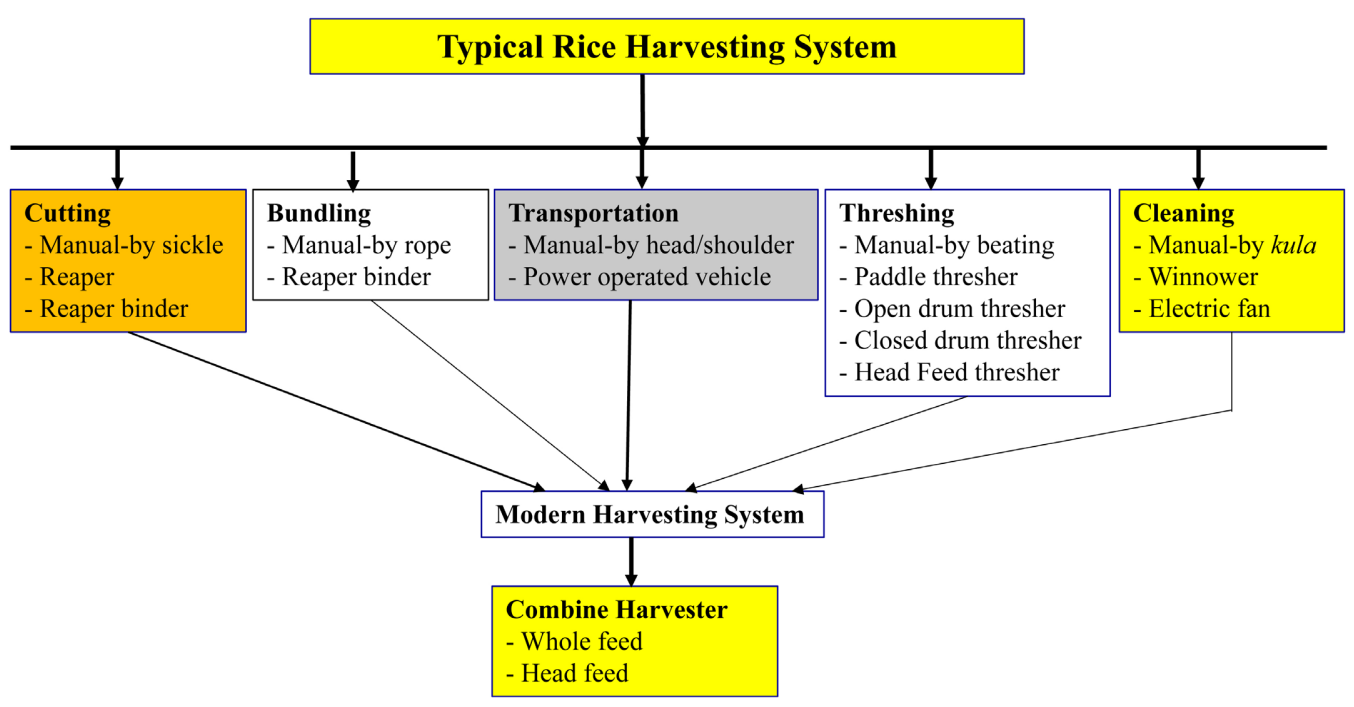

Figure 1. Flow diagram of present harvesting system in Bangladesh.

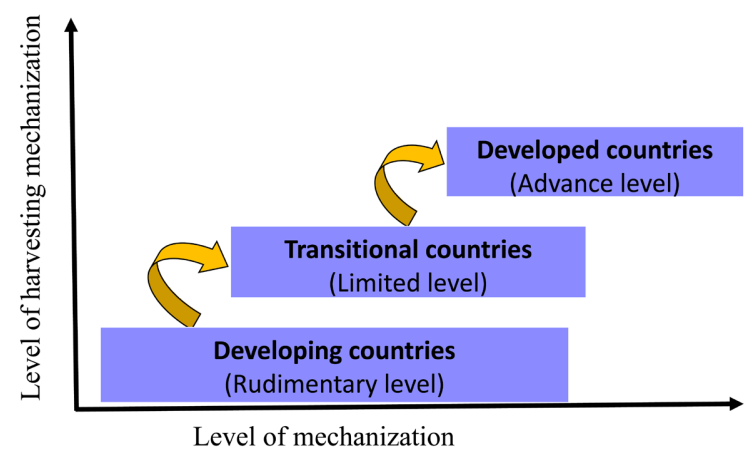

Figure 2. Schematic diagram of mechanization.

However, manual harvesting, mostly cutting and transportation associated with struggle, laborious, costly and huge postharvest losses.

On the other hand, mechanized harvesting offers farmers various benefits as 1) less cost per unit; 2) timely harvesting; 3 ) keep on both quality and quantity; 4) contribute to expanding total productivity; and 5) provide a sustainable, cost-effective transition of the labor pool (Figure 3). As a result, harvest mechanization has received considerable attention globally, to the farmers, researchers, policymakers due to its substantial beneficial consequence. Also, individual farmers, co-operatives, and government stakeholders have used various harvesting technology to make profitable agricultural (Table 1). Moreover, public and private organization are likely to research and develop machinery suitable for Bangladesh conditions (Table 2). Nevertheless, Bangladesh perspective has no sufficient information on harvest mechanization. Therefore, the present study's primary objectives are to bring detailed information on combine harvester use that involves harvesting cost, economic outturns, machinery efficiency, etc.

In addition, farmers in developing and developed nations are terrified about the technological performance of farm machinery. Hence, the adoption rate of 
Table 1. Harvesting machinery available and area coverage in Bangladesh.

\begin{tabular}{|c|c|c|c|c|c|}
\hline \multirow{2}{*}{ Operation } & \multirow{2}{*}{$\begin{array}{l}\text { Name of } \\
\text { machinery }\end{array}$} & \multirow{2}{*}{$\begin{array}{l}\text { Number } \\
\text { of units }\end{array}$} & \multicolumn{2}{|c|}{ Area coverage } & \multirow{2}{*}{ References } \\
\hline & & & Manual & Mechanized & \\
\hline \multirow{3}{*}{ Harvesting } & Sickle & - & $\begin{array}{c}85 \% \\
\text { manual }\end{array}$ & $5 \%$ & {$[12]$} \\
\hline & Reaper & $>650$ & & $>2 \%$ & [18] [19] \\
\hline & Combine harvester & $>1600$ & & $15 \%$ & [20] \\
\hline Hulling & Thresher & $\begin{array}{c}\text { About } \\
390,000\end{array}$ & $4 \%$ & $95 \%$ & {$[21]$} \\
\hline Cleaning & Winnower & About 750 & $85 \%$ & $5 \%$ & [18] [19] \\
\hline
\end{tabular}

Table 2. Research organization and developed technology for paddy harvesting in Bangladesh.

\begin{tabular}{|c|c|c|c|}
\hline $\begin{array}{c}\text { Research } \\
\text { Institute/Organization }\end{array}$ & $\begin{array}{l}\text { Developed } \\
\text { technology }\end{array}$ & $\begin{array}{l}\text { Suitable } \\
\text { for crops }\end{array}$ & References \\
\hline $\begin{array}{c}\text { Bangladesh } \\
\text { Rice Research } \\
\text { Institute }\end{array}$ & $\begin{array}{l}\text { Reaper (Power tiller } \\
\text { operated, } \\
\text { self-propelled, Hand } \\
\text { reaper) } \\
\text { - Thresher (Paddle } \\
\text { thresher, Open drum } \\
\text { thresher, close drum } \\
\text { thresher, Head feed } \\
\text { thresher), } \\
\text { - Small combine } \\
\text { harvester } \\
\text { - Winnower } \\
\text { - Dryer } \\
\text { (Flatbed, Seed dryer) }\end{array}$ & Rice and wheat & [22] \\
\hline $\begin{array}{c}\text { Bangladesh } \\
\text { Agricultural } \\
\text { Research Institute }\end{array}$ & $\begin{array}{l}\text { - } \text { Reaper } \\
\text { - Thresher } \\
\text { - Winnower } \\
\text { - Dryer }\end{array}$ & Rice and wheat & [23] \\
\hline $\begin{array}{l}\text { Bangladesh } \\
\text { Agricultural } \\
\text { University }\end{array}$ & $\begin{array}{l}\text { - } \text { Reaper } \\
\text { - Thresher } \\
\text { - Winnower } \\
\text { - Dryer }\end{array}$ & Rice and wheat & {$[24]$} \\
\hline
\end{tabular}

technology is prolonged in most Asian countries, like Bangladesh. However, as the combine harvester is modern technology, the farmers of Bangladesh are not updated about use and handling. Moreover, the farmers are poor, so they have no capital to purchase the machine. Also, farmers have no idea about the benefits of combine harvester. Therefore, the above reasons are the main point of lack behind mechanization. 


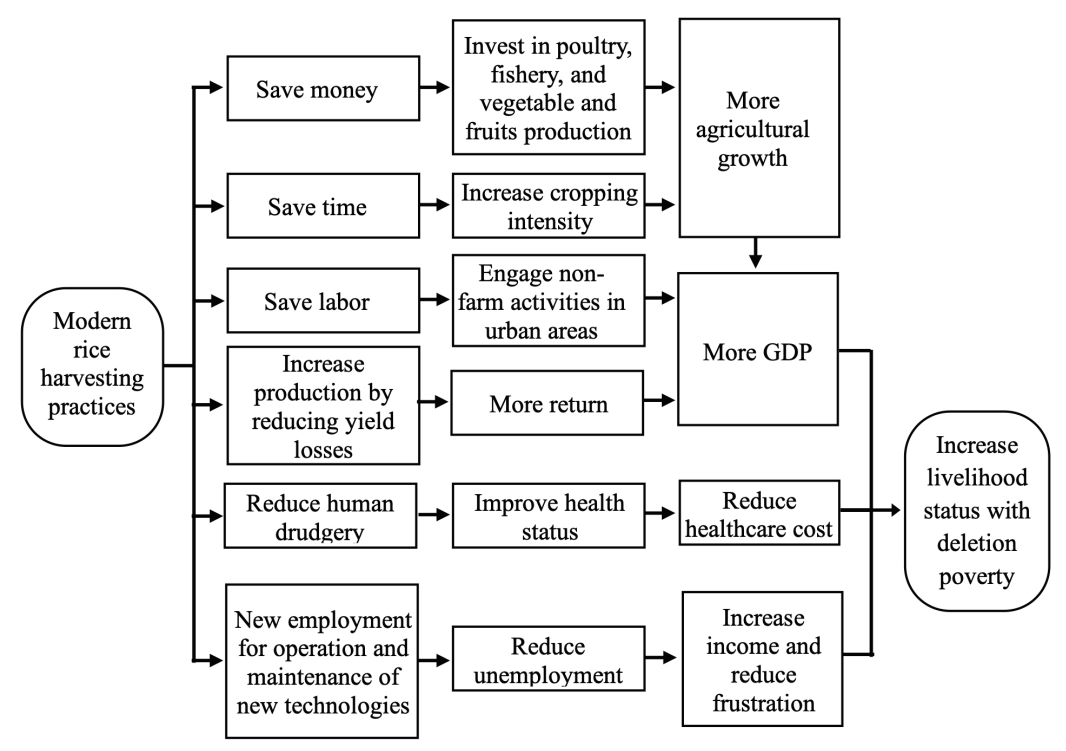

Figure 3. Outline of harvesting mechanization benefits (Adopted from [25]).

Last decade, the farmers and policy levels increasingly adopted the machinery used frequently. However, there is very little up-to-date information regarding harvesting machinery such as reaper, thresher, winnower, bagging system, and overall combine harvester in Bangladesh. Also, harvesting machinery sustainability rates are low; still, the reason is unknown. [25] mentions that the government's knowledge gap and economic support were the main reasons for the low adoption rate of machinery in Bangladesh. [26] also noted that appropriate farm machinery adoption could be an essential policy and development goal of Bangladesh. The Government of Bangladesh has recently prioritized harvesting mechanization for food availability [27]. However, many vital aspects of combine harvester's as labor required to harvest unit area, harvesting losses, feasibility with Bangladesh land perspectives are poorly understood, so comprehensive harvesting mechanization is not well documented. The adoption of ultimate harvesting machinery (combine harvester) needs detailed information like human drudgery, cropping intensity, crop productivity, etc. Also, a machine's technical and economic performance is required to conclude the benefit. Therefore, the study was undertaken to gather specific information on harvest mechanization by combining harvester in Bangladesh.

\section{Research Project and Methodology}

\subsection{Range of Data Arrangement}

The field experiment was conducted in the Gazipur district, Bangladesh, to determine harvesting machinery's work efficiency in Boro 2016 to 2018 season (April-May). The study focused on operation cost, labour-saving and work efficiency for mechanized, semi-mechanized and traditional practice. Research undertook commonly practised actions and machinery to cut, transport, thresh, and clean paddy. 


\subsection{Field Operation Techniques}

Many variations in the farmers' harvesting, threshing, and cleaning practices. Therefore, the following three methods, combined with traditional and modern harvesting, threshing and cleaning, were evaluated to determine work efficiency and economics (Table 3).

\subsection{Procedure to Determine the Work Efficiency}

This study explored the work efficiency, economic analysis and postharvest loss methods from a book chapter by [28]. Method $1\left(\mathrm{~T}_{1}\right)$ incorporated with paddy cutting by sickle, transported the harvested paddy by head or shoulder, threshed the paddy by beating and finally cleaned by Kula. Alternatively, reaper for paddy harvesting, trolly for harvested paddy transportation, close drum thresher for threshing and winnower for cleaning was considered for method $2\left(\mathrm{~T}_{2}\right)$. Both the $T_{1}$ and $T_{2}$, binding techniques were the same pattern (manually). Process $\left(T_{3}\right)$ was fully mechanized vis-a-vis using a combine harvester. The performance indicating methods are:

Method, $\mathrm{T}_{1}$ : Sickle + Head carry + beating + Kula

Method, $\mathrm{T}_{2}$ : Reaper + Trolly carry + Close drum thresher + winnower

Method, $\mathrm{T}_{3}$ : Combine harvester

The machine's efficiency is defined as the device's useful work to the actual work. This activity included beating, close drum thresher, winnower and combine harvester. The field size or sample size was necessarily large to ensure greater accuracy. Before the final test, a pre-test was arranged to minimize the error and adjusted. Box 1 depicts the work efficiency test activity for performance indicating methods $\left(T_{1}, T_{2}\right.$ and $\left.T_{3}\right)$. Undertook some empirical equations for calculating work efficiency, economic analysis and postharvest losses.

\subsection{Selection of Machinery}

Machinery and equipment selection is vital in obtaining reliable and accurate field results. The assorted machinery is listed in Table 4 to conduct the field experiment. The central machinery is Korean made head feed combine harvester.

Table 3. Field operation methods.

\begin{tabular}{|c|c|c|c|c|c|}
\hline \multirow[b]{2}{*}{ Operation } & \multirow[b]{2}{*}{ Parameter } & \multicolumn{3}{|c|}{ Tools } & \multirow[b]{2}{*}{ Collected Data } \\
\hline & & $\begin{array}{l}\text { Method } 1 \\
\left(T_{1}\right)\end{array}$ & $\begin{array}{l}\text { Method } 2 \\
\left(T_{2}\right)\end{array}$ & $\begin{array}{c}\text { Method } 3 \\
\left(\mathrm{~T}_{3}\right)\end{array}$ & \\
\hline Reaping & Cutting, bundling & Sickle & Reaper & & Time, number of labor per unit area \\
\hline Field transport & $\begin{array}{l}\text { Bundling and } \\
\text { transportation }\end{array}$ & \multicolumn{2}{|c|}{ Head and shoulder carry } & \multirow{3}{*}{$\begin{array}{l}\text { Combine } \\
\text { harvester }\end{array}$} & Time and labor requirement \\
\hline Threshing & Threshing and cleaning & Beating & Close drum & & Time, labor and fuel requirement \\
\hline Cleaning/winnowing & cleaning & Kula & thresher & & Time, labor and fuel requirement \\
\hline
\end{tabular}


Table 4. Listed machinery/activity and main specifications.

\begin{tabular}{|c|c|c|c|}
\hline Machinery/activity & Image & Machinery/activity & Image \\
\hline $\begin{array}{c}\text { Combine harvester } \\
\text { Model: KukJe DKC } 925 \\
\text { Country of origin: Korea } \\
\text { Power: } 62 \mathrm{Hp} \\
\text { Cutting width: } 120 \mathrm{~cm}\end{array}$ & & $\begin{array}{l}\text { Beating (threshing) } \\
\text { Type: drum beating } \\
\text { Operator: two } \\
\text { Capacity: } 0.3-0.5 \text { ton } \cdot \mathrm{h}^{-1}\end{array}$ & \\
\hline $\begin{array}{c}\text { Reaper } \\
\text { Model: BRRI developed } \\
\text { Power. } 16 \mathrm{Hp} \text { diesel engine } \\
\text { Cutting width: } 100 \mathrm{~cm} \\
\text { Capacity: } 0.15 \text { ha }\end{array}$ & & $\begin{array}{c}\text { Winnower } \\
\text { Model: BRRI developed } \\
\text { Power: } 4 \text { Hp diesel engine } \\
\text { Capacity: } 0.5 \text { ton } \cdot \mathrm{h}^{-1}\end{array}$ & \\
\hline $\begin{array}{l}\text { Close drum thresher } \\
\text { Model: BRRI TH-7 } \\
\text { Country of origin: Korea } \\
\text { Power: } 16 \text { Hp diesel engine } \\
\text { Capacity: } 1-1.5 \text { tone } \cdot \mathrm{h}^{-1}\end{array}$ & & $\begin{array}{c}\text { Kula (cleaning) } \\
\text { Type: Human power use } \\
\text { Operator one } \\
\text { Capacity: } 0.15-0.2 \text { tone } \cdot \mathrm{h}^{-1}\end{array}$ & \\
\hline
\end{tabular}

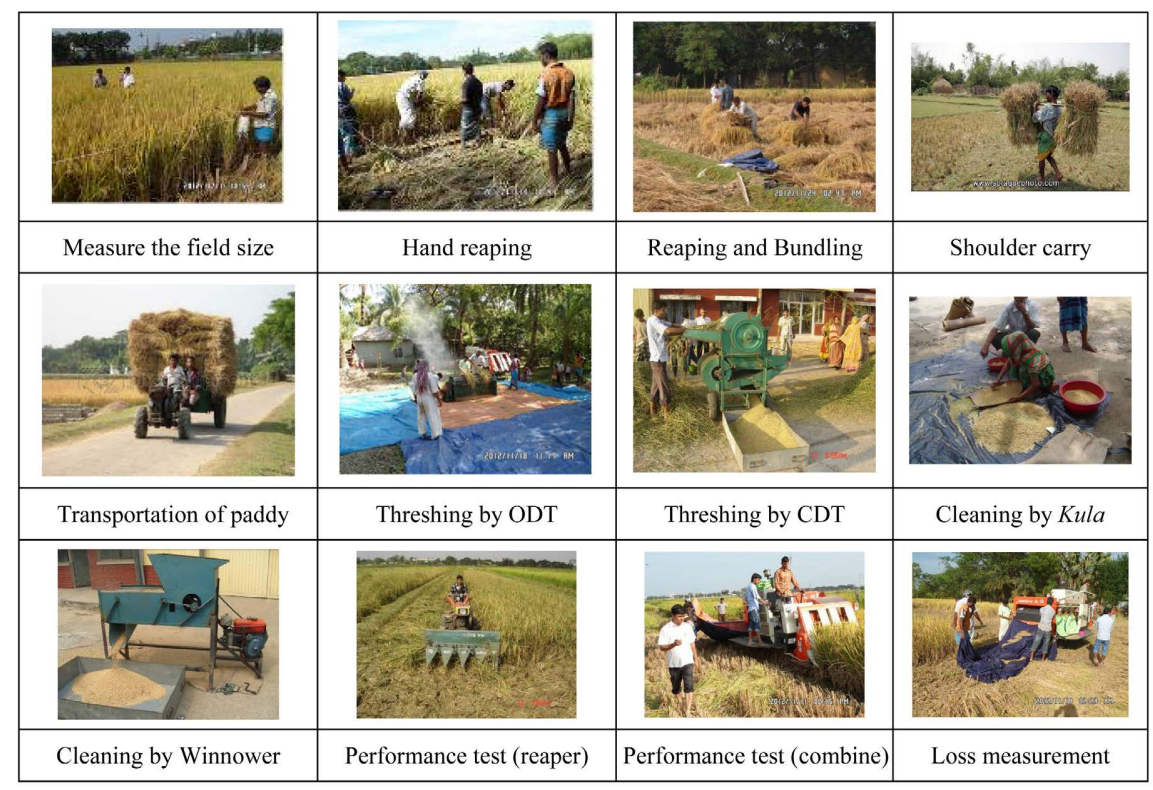

Box 1. Pictorial view of work efficiency test activity.

\subsection{Performance Parameter}

The performance factors are listed to evaluate a combine harvester's technical and economic efficiency during paddy harvesting and compare with other harvesting systems. The performance elements were: 1) labor per unit area, 2) field capacity, 3) field efficiency, 4) operational time, 5) operating cost and 6) grain losses.

\subsubsection{Work Efficiency Calculation}

Field efficiency/work efficiency is the ratio between a machine's productivity 
under field conditions and the theoretical maximum productivity. Field efficiency accounts for failure to utilize the machine's theoretical operating width; time lost because of operator capability and habits and operating policy; and field characteristics. The calculation did not include travel to and from a field, significant repairs, preventive maintenance, and daily service activities for field time or efficiency. Field efficiency is not a constant for a particular machine but varies with the field's size, shape and pattern, crop yield, moisture, and crop conditions. This study used the following formula to calculate work efficiency.

Labor per unit area

$$
M P A=\frac{T W \times P W}{60 A W}
$$

where,

$M P A$ : labor per unit area, man-h.ha ${ }^{-1}$

$T W$ : working time for harvesting process, min

$P W$ : working person, $\mathrm{m}$

$A W$ : working area for harvesting process ha)

\section{Theoretical field capacity}

$$
C_{\text {th }}=0.36 \mathrm{~W} \cdot \mathrm{V}
$$

where,

$C_{t t}:$ Theoretical field capacity, ha. $\mathrm{h}^{-1}$

$W$ : Theoretical working width, $\mathrm{m}$

$V$ : Theoretical working speed of the machine, $\mathrm{m} \cdot \mathrm{s}^{-1}$

Theoretical operation time

$$
T_{t h}=\frac{A}{C_{t h}}=\frac{A}{0.36 W \cdot V}
$$

where,

$T_{t h}$ : Theoretical operation time, $\mathrm{min}$

$A$ : Area of a plot, ha

$W$ : Theoretical working width, $\mathrm{m}$

$V$ : Theoretical working speed of the machine, $\mathrm{m} \cdot \mathrm{s}^{-1}$

Actual field capacity and efficiency

Actual field capacity and efficiency

$$
\begin{gathered}
C=\frac{A}{T} \\
E_{f}=\frac{C}{C_{t h}}
\end{gathered}
$$

where,

$C$ : Field capacity, ha $\cdot \mathrm{h}^{-1}$

$A$ : Area of a plot, ha

$T$ : Field operation time

$E_{f}$ : Field efficiency 
$C_{t h}:$ Theoretical field capacity, ha $\cdot \mathrm{h}^{-1}$

\section{Area coverage}

$$
H=\frac{\varepsilon_{u} \cdot \varepsilon_{d} \cdot C \cdot U \cdot D}{N}
$$

where,

$H$ : Coverage, ha

$\mathcal{E}_{u}$ : Network hour rate

$\mathcal{E}_{d}$. Available working day rate

$C$. Field capacity, ha $\cdot h^{-1}$

$U$ : Daily operation time, $\mathrm{h}$

$D$ : Duration of operation, day

$N$ : Number of operations

\section{Turns number}

$$
\begin{gathered}
n_{180}=N_{s y}-2 N_{c}-1 \\
n_{90}=4 N_{c} \\
N_{c}=2 I N T\left(\frac{l_{m}}{w}\right) \\
N_{s y}=\frac{x-2 N_{c} w}{w}
\end{gathered}
$$

where,

$n_{180}$ : Number of 180 degree turns

$N_{s y}$ : Number of run-strokes alongside the long side

$N_{c}$ : Number of circuitous turns

$n_{90}$ : Number of 90 degree turns

$I_{m}$ : Length of machine, $\mathrm{m}$

$w$. Effective working width, $\mathrm{m}$

$x$. Width of unit field, $m$

\section{Operation time}

$$
\begin{aligned}
& T=T_{e}+T_{\text {loss }} \\
& T_{e}=\frac{x \cdot y}{60 \mathrm{v} \cdot \mathrm{w}} \\
& T_{\text {loss }}=T_{\text {turn }}+T_{\text {idle }}+T_{p f}+T_{\text {io }}
\end{aligned}
$$

where,

$T$ : Field operation time, min

$T_{e}$ : Total time requirement for operation, $\min$

$T_{\text {loss: }}$ Loss time, min

$T_{\text {turn: }}$ Turning time, $\min$

$T_{\text {idle: }}$ Idle travel time, min

$T_{p t}$ Preliminary or finishing operation time, min

$T_{i o}$ : Time for getting in and out field, min

$x$. Width of unit field, $\mathrm{m}$ 
$y$. Length of unit field, $\mathrm{m}$

$v$. Working speed of machine, $\mathrm{m} / \mathrm{s}$

$w$. Effective working width, $\mathrm{m}$

Time calculation

$$
\begin{gathered}
T_{\text {turn }}=\left(n_{180} \cdot t_{180}+n_{90} \cdot t_{90}\right) / 60 \\
T_{\text {idle }}=\frac{y}{60 \mathrm{v}} \\
T_{p f}=\frac{2(x+y)}{60 \mathrm{v}}
\end{gathered}
$$

where,

$T_{\text {turn: }}$ Turning time, $\min$

$n_{180}$ : Number of 180 degree turns

$t_{180}$ : Time for a 180 degree turn, $\mathrm{s}$

$n_{90}$ : Number of 90 degree turns

$t_{90}$ : Time for a 90 degree turn, $\mathrm{s}$

$T_{\text {idlle: }}$ Idle travel time, $\min$

$y$. Length of unit field, $\mathrm{m}$

$v$. Working speed of machine, $\mathrm{m} \cdot \mathrm{s}^{-1}$

$T_{p}$ : Preliminary or finishing operation time, min

$x$. Width of unit field, $\mathrm{m}$

$T_{i 0}$ : Time for getting in and out of field, $\min =5$

\subsubsection{Economic Analysis}

Economic analysis is obligatory for concluding any technology is viable, suitable and fit for farmers. The study's main objective is to derive the benefit and cost of rice combine harvester investment and its economic returns by applying the basic concept of an analysis of investment returns.

\section{Operating cost}

$$
\begin{aligned}
& Y C=F C+Y V C \\
& F C=D P_{0}+R C
\end{aligned}
$$

where,

$Y C$ : Annual operating cost, $\mathrm{Tk} \cdot \mathrm{yr}^{-1}$

$F C$ : Annual fixed cost, $\mathrm{Tk} \cdot \mathrm{yr}^{-1}$

$Y V C$ : Annual variable cost, $\mathrm{Tk} \cdot \mathrm{yr}^{-1}$

$D P_{0}$ : Depreciation cost, $\mathrm{Tk} \cdot \mathrm{yr}^{-1}$

$R C$ : Annual repair cost, $\mathrm{Tk} \cdot \mathrm{yr}^{-1}$

Fixed cost

$$
\begin{aligned}
& D P_{O}=\frac{P-S}{n} \\
& R C=P \cdot y r f
\end{aligned}
$$

where, 
$D P_{O}$ : Depreciation by straight-line method, $\mathrm{Tk} \cdot \mathrm{yr}^{-1}$

$P$. Purchase price, $\mathrm{Tk}$

$S$ : Salvage value, Tk

$n$ : Service life in years

$R C$ : Annual repair cost, $\mathrm{Tk} \cdot \mathrm{yr}^{-1}$

yrf. Annual repair cost factor, 0.05

Variable cost

$$
\begin{gathered}
Y V C=U H R \times 2.4(F O H+L H) \\
F O H=F U P \cdot F U R(1+O F R) \\
L H=W A G(1.3 N O P+N A U) \\
U H R=\frac{A R}{C}
\end{gathered}
$$

where,

$Y V C$ : Annual variable cost, $\mathrm{Tk} \cdot \mathrm{yr}^{-1}$

$U H R$ : Yearly available working time, $\mathrm{h} \cdot \mathrm{yr}^{-1}$

FOH: Fuel and oil cost per hour, $\mathrm{Tk} \cdot \mathrm{h}^{-1}$

$L H$ : Labor cost per hour, Tk.h ${ }^{-1}$

FUP: Fuel price, TK. $1^{-1}$

FUR: Fuel consumption per hour, $1 \cdot \mathrm{h}^{-1}$

$O F R$ : The ratio of oil and fuel cost

$W A G$ : Wage per hour, $\mathrm{Tk} \cdot \mathrm{h}^{-1}$

NOP: Number of operators

$N A U$ : Number of auxiliary operators

$A R$ : Area of machine management, ha $\cdot \mathrm{yr}^{-1}$

$C$. Field capacity, ha $\mathrm{h}^{-1}$

\subsubsection{Postharvest Losses}

In the experiment, for harvesting losses measurement, considered the following formula. Generally, there are three types of losses for combine harvester (shatter/cutter bar loss, cylinder/threshing loss and separating/cleaning loss). However, the losses are five types in a traditional system (Shattering/cutting loss, bundling loss, transportation loss, threshing loss and cleaning loss).

$$
\begin{gathered}
\text { Area Factor }(A F)=\frac{\text { Total area }}{\text { Loss estimated area }} \\
\text { Moisture Conversation Factor }(M C F)=\frac{100-M_{0}}{86}
\end{gathered}
$$

where $M_{0}=$ Initial Moisture

Total obtained yield $(\mathrm{kg})=$ Total wet wt. $(\mathrm{kg}) \times M C F$

Total cutting loss wt. $(\mathrm{g})=$ cutting loss wt. $(\mathrm{g}) \times M C F \times A F$

$$
\text { Cutting loss, } \%=\frac{\text { Total cutting loss wt }(\mathrm{g})}{\text { Total obtained yield }(\mathrm{kg})} \times \frac{1}{10}
$$


Total bundling loss wt. $(\mathrm{g})=$ Bundling wet wt. $(\mathrm{g}) \times M C F$

$$
\text { Bundling loss, } \%=\frac{\text { Total bundling loss } \mathrm{wt}(\mathrm{g})}{\text { Total obtained yield }(\mathrm{kg})} \times \frac{1}{10}
$$

Total transportation loss wt $(\mathrm{g})=$ Transportation loss wet wt. $(\mathrm{g}) \times M C F$

$$
\text { Transportation loss, } \%=\frac{\text { Total transportation loss wt. }(\mathrm{g})}{\text { Total obtained yield }(\mathrm{kg})} \times \frac{1}{10}
$$

Total threshing loss wt. $(\mathrm{g})=$ Threshing loss wet wt. $(\mathrm{g}) \times M C F$

$$
\text { Threshing loss, } \%=\frac{\text { Total threshing loss wt }(\mathrm{g})}{\text { Total obtained yield }(\mathrm{kg})} \times \frac{1}{10}
$$

Total cleaning loss wt. $(\mathrm{g})=$ Cleaning loss wet wt. $(\mathrm{g}) \times M C F$

$$
\text { Cleaning loss, } \%=\frac{\text { Total cleaning loss wt. }(\mathrm{g})}{\text { Total obtained yield }(\mathrm{kg})} \times \frac{1}{10}
$$

Total postharvest loss $=$ Cutting loss + Bundling loss + Transportation loss

$$
+ \text { Threshing loss + Cleaning loss }
$$

\subsubsection{Technique of Simulation}

Simulation and calculation are integral parts of analysis. For forecasting, actual condition simulation is necessary. Sometimes the simulation value is higher or lower, thus showing the actual condition. Simultaneously improved and developed by simulation are required to achieve the fundamental components quickly. For getting the accurate information of combine harvester, here simulation was considered.

\section{Results and Discussion}

\subsection{Work Efficiency}

Work efficiency is a significant factor to evaluate the technology. The total workforce requirement of $\mathrm{T}_{1}\left(278.0 \mathrm{man}-\mathrm{h} \cdot \mathrm{ha}^{-1}\right)$ was comparatively higher than $\mathrm{T}_{2}$ (238.1 man-h.ha ${ }^{-1}$ ) (Table 5). The reaping and transportation capacity was a difference in $T_{1}$ and $T_{2}$. The reaping capability depends on planting intensity, the cutting plant's height, and labor skill. A hand beating capacity is lower than a close drum thresher, so the labor requirement for threshing is in an inverse relationship. On the other hand, the paddy comes clean in a closed drum thresher because most threshers have cleaning facilities.

Table 6 expresses the combine and actual/simulation with field test (analysis) working efficiency. Here, the working width and theoretical field capacity are the same, but the total working time is different. The analysis result is higher than the combine test result because the analysis considered the machine's time to enter and leave the field. So, the actual (analysis result) field efficiency, field capacity and coverage were higher than the combine harvester's work. The combined labour requirement $\left(6.37 \mathrm{man}-\mathrm{h} \cdot \mathrm{ha}^{-1}\right)$ was lower than the analysis result (9.87 man-h.ha ${ }^{-1}$ ). 
Table 5. Working capacity analysis.

\begin{tabular}{|c|c|c|}
\hline Particular & $\mathrm{T}_{1}$ & $\mathrm{~T}_{2}$ \\
\hline Field size, length $\times$ width $(\mathrm{m})$ & $50 \times 40$ & $48 \times 40$ \\
\hline Area, ha & 0.2 & 0.192 \\
\hline Cutting time, $\min$ & 1970 & 1384 \\
\hline Cutting labor per unit area, man-h.ha ${ }^{-1}$ & 164 & 120 \\
\hline Transporting time, min & 790 & 260 \\
\hline Transporting labor per unit area, man-h.ha ${ }^{-1}$ & 66 & 23 \\
\hline Threshing time, min & 552 & 62 \\
\hline Threshing labor per unit area, man-h.ha ${ }^{-1}$ & 46 & 5 \\
\hline Cleaning time, $\min$ & 88 & 68 \\
\hline Cleaning labor per unit area, man-h.ha $\mathrm{a}^{-1}$ & 7 & 6 \\
\hline Total labor per unit area, man-h.ha ${ }^{-1}$ & 283 & 154 \\
\hline
\end{tabular}

Table 6. Working efficiency of the combine harvester.

\begin{tabular}{|c|c|c|}
\hline Particulars & $\begin{array}{c}\text { Combine } \\
\left(\mathrm{T}_{3}\right)\end{array}$ & Simulation \\
\hline Field size, length $\times$ width & $50 \times 40$ & $50 \times 40$ \\
\hline Area, ha & 0.2 & 0.2 \\
\hline Working width, $\mathrm{m}$ & 1.45 & 1.45 \\
\hline Working speed, $\mathrm{m} \cdot \mathrm{s}^{-1}$ & 1.20 & 1.20 \\
\hline Theoretical field capacity, ha. $\mathrm{h}^{-1}$ & 0.64 & 0.64 \\
\hline Total working time, min & 31.36 & 48.58 \\
\hline Field capacity at plot, ha. $\mathrm{h}^{-1}$ & 0.38 & 0.25 \\
\hline Field efficiency, \% & 60.12 & 38.79 \\
\hline Coverage, ha $\cdot \mathrm{yr}^{-1}$ & 78.06 & 50.37 \\
\hline Number of operators, man & 1 & 1 \\
\hline Number of auxiliary operators, man & 1 & 1 \\
\hline Labor requirement per unit area, man-h.ha ${ }^{-1}$ & 6.37 & 9.87 \\
\hline
\end{tabular}

\subsection{Comparison of Labor Requirement per Unit Area/Labor Saved}

Labor involvement during paddy harvesting is a vital factor in harvesting costs. Table 7 compares the labor required for $T_{1}, T_{2}$ and $T_{3}$. Here, $T_{1}$ requires 28.67 times more labor and $\mathrm{T}_{2}$ requires 15.6 times more labor than combine harvester. [29] notices that rice manual harvesting is a laborious, time-consuming and 
Table 7. Comparison of labor requirement (man-h/ha).

\begin{tabular}{cccc}
\hline Particulars & $\mathrm{T}_{1}$ & $\mathrm{~T}_{2}$ & $\begin{array}{c}\mathrm{T}_{3} \\
\text { (Combine harvester) }\end{array}$ \\
\hline $\begin{array}{c}\text { Labor requirement per unit area, man-h.ha }{ }^{-1} \\
\text { Ratio per combine }\end{array}$ & 283 & 154 & 9.87 \\
\hline
\end{tabular}

costly operation that requires about $100-150$ persons to harvest 1 ha of paddy field and was responsible for both quality and quantity losses.

So the use of combine harvester was more effective than traditional reaping, transportation and threshing. The combine harvester does not require bundling, transportation, and winnowing because the reaping, threshing, and cleaning are done simultaneously. Ultimately, combine harvester is the most significant and commercially labor-saving invention and significantly reduces labor requirements in agriculture [30].

\subsection{Area Coverage of Combine Harvester}

Table 8 shows the coverage calculation for the combine harvester. The plot geometry coverage was $156.11 \mathrm{ha} \cdot \mathrm{yr}^{-1}$, which was higher than the actual (simulation) coverage of $100.73 \mathrm{ha} \cdot \mathrm{yr}^{-1}$. However, this result was not correct because the plot size was small. Therefore, the experiment should be carried out in a big field for a better and more reliable result. Here, we consider only two seasons per year. But in some areas, rice is grown three times. So depending on the crop growing region, the area coverage may need to be changed.

\subsection{Economic Analysis of Paddy Harvesting Cost}

Table 9 compared the operating cost of methods $T_{1}, T_{2}$ and $T_{3}$. For traditional practice $\left(\mathrm{T}_{1}\right)$, all operations during paddy harvesting were cleaned manually. Alternatively, the semi-mechanization process $\left(\mathrm{T}_{2}\right)$ was done by machine as a reaper for harvesting, bundling by hand, power tiller operated trolley for transportation, close drum thresher for threshing winnower for cleaning (Table 9). Cost calculated according to the needed man-day per hectare. As shown in the table, the harvesting costs were 1.84 (semi-mechanization) and 2.5 (manual) times higher lower than the combine harvester. The like outcome by [31] and research demonstrated that mechanization production cost decreased from 4 to 10 -fold (Table 10).

\subsection{Cost Calculation}

Reducing harvesting costs as a percentage of total production costs is one of mechanization's main factors. Modern harvesting technologies are already adopted in developing countries to maintain grain quality [10]. Table 11 provides the economic analysis for the combine harvester operation cost calculation. This table also expresses the simulation of combine operating costs. The fixed 
Table 8. Annual area coverage of combine harvester.

\begin{tabular}{ccc}
\hline Particulars & $\mathrm{T}_{3}$ & Simulation \\
\hline Total working hour per season, h-season ${ }^{-1}$ & 203.88 & 203.88 \\
Network rate & 0.82 & 0.82 \\
Ratio of available working days & 0.84 & 0.84 \\
Daily operation time, h & 8 & 8 \\
Working period, days & 37 & 37 \\
Number of crop seasons in a year & 2 & 2 \\
Coverage at the plot geometry, ha.yr ${ }^{-1}$ & 156.11 & 100.73 \\
\hline
\end{tabular}

Table 9. Comparison of paddy harvesting cost.

\begin{tabular}{|c|c|c|c|c|c|c|}
\hline \multirow[b]{2}{*}{ Item } & \multicolumn{2}{|l|}{$\mathrm{T}_{1}$} & \multicolumn{2}{|l|}{$\mathrm{T}_{2}$} & \multicolumn{2}{|l|}{$\mathrm{T}_{3}$} \\
\hline & $\begin{array}{c}\text { No of } \\
\text { man-day } \cdot \mathrm{ha}^{-1}\end{array}$ & $\begin{array}{c}\text { Cost, } \\
\text { Tk } \cdot \mathrm{ha}^{-1}\end{array}$ & $\begin{array}{c}\text { No of } \\
\text { man-day } \cdot \mathrm{ha}^{-1}\end{array}$ & $\begin{array}{c}\text { Cost, } \\
\text { Tk.ha }{ }^{-1}\end{array}$ & $\begin{array}{c}\text { No of } \\
\text { man-day } \cdot \text { ha }^{-1}\end{array}$ & $\begin{array}{c}\text { Cost, } \\
\text { Tk.ha }{ }^{-1}\end{array}$ \\
\hline Wage, TK·day ${ }^{-1}(8 \mathrm{~h})$ & - & 500.0 & - & 600.0 & - & 700.0 \\
\hline Fuel price, TK. $1^{-1}$ & - & - & - & 68.0 & - & 68.0 \\
\hline Paddy cutting & 22 & $11,000.0$ & 8 & 4800.0 & 4 & 2800.0 \\
\hline Paddy bundling and transportation to yard & 14 & 7000.0 & 14 & 8400.0 & $2^{*}$ & 1400.0 \\
\hline Paddy threshing & 12 & 6000.0 & 8 & 4800.0 & $4^{* *}$ & 2800.0 \\
\hline Paddy thresher fuel, $1 \cdot h^{-1}$ & - & - & 4 & 272.0 & & 3944.0 \\
\hline Paddy cleaning & 7 & 3500.0 & 3 & 1800.0 & - & - \\
\hline Paddy winnower fuel, $1 \cdot \mathrm{ha}^{-1}$ & - & - & 2 & 136.0 & - & - \\
\hline Total harvesting cost, TK.ha- ${ }^{-1}$ & & $27,500.0$ & & $20,208.0$ & & $10,944.0$ \\
\hline Total harvesting cost, UD $\mathbf{\$} \cdot \mathrm{ha}^{-1}$ & & 328.0 & & 241.0 & & 131.0 \\
\hline Ratio per combine & & 2.5 & & 1.84 & & 1 \\
\hline
\end{tabular}

Note: 84.0 Bangladeshi Taka $(\mathrm{Tk})=1 \mathrm{US} \$ ;{ }^{\star}$ Paddy carrying; ${ }^{\star \star}$ Straw binding and carrying.

Table 10. Economic analysis of combine harvester.

\begin{tabular}{ccc}
\hline Item & Unit & Combine harvester \\
\hline Machine price & $\mathrm{TK}$ & $1,800,000.0$ \\
Service life & $\mathrm{yr}$ & 7 \\
& $\mathrm{TK} \cdot \mathrm{yr}^{-1}$ & $244,286.0$ \\
Annual fixed cost & $\mathrm{TK}^{-\mathrm{ha}^{-1}}$ & 3054.0 \\
Variable cost & $\mathrm{TK}^{-\mathrm{yr}^{-1}}$ & $614,131.0$ \\
& $\mathrm{TK}^{-\mathrm{ha}^{-1}}$ & 7677.0 \\
\hline
\end{tabular}




\section{Continued}

Operating cost

Operating area/Break-even use

Manual harvesting cost

Cost save
$858,417.0$

$10,730.0$

40

$27,500.0$

61

Note: ${ }^{\star}$ two rice-growing seasons yearly.

Table 11. Percent loss estimates in rice for the harvesting system.

\begin{tabular}{cccc}
\hline Operations & $\mathrm{T}_{1}$ & $\mathrm{~T}_{2}$ & $\mathrm{~T}_{3}$ \\
\hline Cutting loss (\%) & 0.49 & 0.39 & 0.13 \\
Stacking/bundling loss (\%) & 0.44 & 0.38 & - \\
Transportation loss (\%) & 0.21 & 0.14 & - \\
Threshing loss (\%) & 1.54 & 1.79 & 1.12 \\
Cleaning loss (\%) & 0.40 & 0.24 & - \\
Total harvesting loss (\%) & 3.09 & 2.94 & 1.25 \\
Loss saved over manual harvesting & - & 0.15 & 1.84 \\
\hline
\end{tabular}

price was the same in both combine harvester and simulation; however, variable and operating cost differs. A farmer can save $61 \%$ of the harvesting cost (Table 11). This is similar to [14]'s research result and combine harvester could save $52 \%$ of harvesting cost compared to hand harvest. A field experiment conducted by [32] showed that $58 \%$ and $46 \%$ of expenses were saved using a mini-combine harvester and a reaper.

\subsection{Postharvest Loss}

The postharvest depends on variety, harvesting time (mature/over mature), and natural conditions [10]. Paddy harvesting losses (cutting, bundling, threshing and cleaning) for $\mathrm{T}_{1}, \mathrm{~T}_{2}$ and $\mathrm{T}_{3}$ were determined during Aman season 2016 and summarized in Table 11 . The field experiment was conducted in good weather condition. The weight of grain losses and total yield were encountered for the estimation of losses. Average cutting, bundling, transportation, threshing and cleaning loss for $\mathrm{T}_{1}$ were found $0.49 \%, 0.44 \%, 0.21 \%, 1.54 \%$ and $0.40 \%$, respectively. Alternatively, for $\mathrm{T}_{2}$, the total loss was $2.94 \%$, which was less than traditional harvesting $\mathrm{T}_{1}(3.09 \%)$. [10] and [33] reported that manual harvesting loss is higher than mechanical.

Moreover, the cutting and threshing losses were $0.13 \%$ and $1.25 \%$ in the combine harvester. In a combine, the cleaning (chaff) loss was negligible. Finally, the combine harvester postharvest losses were 3 to 4 times less than traditional $\left(\mathrm{T}_{1}\right)$ and semi-mechanized $\left(\mathrm{T}_{2}\right)$ harvesting systems. As the combine has no transpor- 
tation loss, they can avoid bundling and transport loss if farmers use a combine, ranging from $0.14 \%$ to $0.21 \%$. This result is similar to [32]. They noted that mini-combine and reaper could reduce rice harvesting by $5.12 \%$ and $2.14 \%$, respectively, compared to manual harvesting systems. Regarding postharvest issues, the combine harvester used might benefit the farmers.

It is well-known the loss of paddy could be saved using the combine harvester over manual harvesting and a semi-mechanized system. Paddy loss could be held at $1.84 \%$ using the combine and $0.15 \%$ by the semi-mechanization system (Table 6). [10] [33] [34] reported that grain loss using a combine harvester varies ranging from $1.43 \%$ to $5.6 \%$. Similarly, another study conducted by [35] suggested that mechanical harvesting can avoid a 3\% postharvest loss per season. Therefore, mechanized harvesting is a justified way to reduce postharvest loss and be more feasible and economical than traditional [36].

\section{Conclusions}

Bangladesh's common postharvest practices are harvesting by sickle, field transport on head and shoulder, piling of harvested stalks at the home yard, threshing by hand beating and/or power thresher, and cleaning threshed paddy by winnowing basket (Kula). However, due to colossal government initiatives, mechanical harvesting technology boosts especially harvester popularisation activities. The study showed that less harvesting cost, less labor requirement and low postharvest loss are the primary advantages of a combine harvester. However, even the machine purchasing cost remains beyond the farmer's capacity. However, both the quality and quantity deterioration of grain due to delayed harvesting and profitability are major concerns of manual harvesting. Therefore, for Bangladesh, combine harvester is smart technology for solving big harvesting problems of Bangladesh.

This work characterized a small combine harvester's work efficiency, economic analysis, and postharvest loss assessment and compared manual harvesting's potential impact. However, small-scale combine harvester can benefit Bangladesh's fragmented crop fields and is considered here and has a considerable benefit over the traditional practice. However, these benefits may not be significant enough to outweigh economic factors associated with capital cost, operational expenses and break-even point. Therefore, a complete techno-economic analysis should be conducted to thoroughly explore a small-scale/large combine harvester's relative advantages.

\section{Acknowledgements}

The authors would like to acknowledge the "Strengthening Farm Machinery Research Activity for Mechanized Rice Cultivation (SFMRA) Project" FMPHT Division, BRRI, Bangladesh, for providing the financial support to publish this research work. 


\section{Disclaimer}

The views expressed in this article are those of the authors and do not necessarily represent the Bangladesh Government or the authors' institution and shall not be used for advertising or product endorsement purposes.

\section{Conflicts of Interest}

The authors have declared that there is not a conflict of interest.

\section{Author Contributions}

The article is the result of joint work.

\section{Funding}

The research did not receive any specific grant from funding agencies in the public, commercial, or not-for-profit sectors.

\section{References}

[1] United Nations (2020) World Population Projected to Reach 9.8 Billion in 2050, and 11.2 Billion in 2100 .

https://www.un.org/development/desa/en/news/population/world-population-pros pects-2017.html

[2] Godfray, H.C.J. and Garnett, T. (2014) Food Security and Sustainable Intensification. Philosophical Transactions of the Royal Society B: Biological Sciences, 369, Article ID: 20120273. https://doi.org/10.1098/rstb.2012.0273

[3] Tilman, D., Balzer, C., Hill, J. and Befort, B.L. (2011) Global Food Demand and the Sustainable Intensification of Agriculture. Proceedings of the National Academy of Sciences of the United States of America, 108, 20260-20264. https://doi.org/10.1073/pnas.1116437108

[4] Asian Development Bank (2019) Poverty Data: Bangladesh. https://www.adb.org/countries/bangladesh/poverty

[5] The Global Economy (2020) Bangladesh: Employment in Agriculture. https://www.theglobaleconomy.com/Bangladesh/Employment in agriculture/

[6] World Bank (2016, October 9) Bangladesh: Growing the Economy through Advances in Agriculture.

https://www.worldbank.org/en/results/2016/10/07/bangladesh-growing-economy-t hrough-advances-in-agriculture

[7] BBS (Bangladesh Bureau of Statistics) (2017) Statistical Pocketbook of Bangladesh. Bangladesh Bureau of statistics, Dhaka, Ministry of Planning, Government of Bangladesh, Dhaka.

[8] Mainuddin, M. and Kirby, M. (2015) National Food Security in Bangladesh to 2050. Food Security, 7, 633-646. https://doi.org/10.1007/s12571-015-0465-6

[9] Kabir, M.S., Salam, M.U., Chowdhury, A., Rahman, N.M.F., Iftekharuddaula, K.M., Rahman, M.S., et al. (2015) Rice Vision for Bangladesh: 2050 and Beyond. Bangladesh Rice Journal, 19, 1-18. https://doi.org/10.3329/brj.v19i2.28160

[10] Nath, B.C., Hossen, M.A., Islam, A.K.M.S., Huda, M.D., Paul, S. and Rahman, M.A (2016) Postharvest Loss Assessment of Rice at Selected Areas of Gazipur District. 
Bangladesh Rice Journal, 20, 23-32. https://doi.org/10.3329/brj.v20i1.30626

[11] Abedin, M.Z., Rahman, M.Z., Mia, M.I.A. and Rahman, K.M.M. (2012) In-store Losses of Rice and Ways of Reducing Such Losses at Farmers' Level: An Assessment in Selected Regions of Bangladesh. Journal of the Bangladesh Agricultural University, 10, 133-144. https://doi.org/10.3329/jbau.v10i1.12105

[12] Nath, B.C., Nam, Y.S., Huda, M.D., Rahman, M.M., Ali, P. and Paul, S. (2017) Status and Constrain for Mechanization of Rice Harvesting System in Bangladesh. Agricultural Sciences, 8, 492-506. https://doi.org/10.4236/as.2017.86037

[13] Brolley, M. (2015) Rice Security Is Food Security for Much of the World. Rice Today. International Rice Research Institute (IRRI), Metro Manila, 30-32.

[14] Hasan, M.K., Ali, M.R., Saha, C.K., Alam, M.M. and Hossain, M.M. (2019) Assessment of Paddy Harvesting Practices of Southern Delta Region in Bangladesh. Progressive Agriculture, 30, 57-64. https://doi.org/10.3329/pa.v30i0.41558

[15] Mottaleb, K.A., Krupnik, T.J. and Erenstein, O. (2016) Factors Associated with Small-Scale Agricultural Machinery Adoption in Bangladesh: Census Findings. Journal of Rural Studies, 46, 155-168. https://doi.org/10.1016/j.jrurstud.2016.06.012

[16] Paul, S., Hossen, M., Nath, B., Rahman, M. and Hosen, S. (2016) Effect of Soil Settling Period on Performance of Rice Transplanter. International Journal of Sustainable Agricultural Technology, 12, 14-20.

[17] Hossen, M., Talukder, M., Amin, R., Al Mamun, M.R., Rahaman, H., Paul, S., et al. (2020) Mechanization Status, Promotional Activities and Government Strategies of Thailand and Vietnam in Comparison to Bangladesh. AgriEngineering, 2, 489-510. https://doi.org/10.3390/agriengineering2040033

[18] Ahmed, S. (2014, November) Country Paper Presentation, Bangladesh. The 10th Session of the Technical Committee of CSAM and Regional Workshop on Establishing a Regional Database of Agricultural Mechanization in Asia and the Pacific, Siem Reap, 17-19 November 2014, 17-19.

[19] Tiwari, P.S., Gurung, T.R., Sahni, R.K. and Kumar, V. (2017) Agricultural Mechanization Trends in SAARC Region. Mechanization for Sustainable Agricultural Intensification in SAARC Agriculture Centre, Dhaka, 302.

[20] Hasan, M.K., Ali, M.R., Saha, C.K., Alam, M.M. and Haque, M.E. (2019) Combine Harvester: Impact on Paddy Production in Bangladesh. Journal of the Bangladesh Agricultural University, 17, 583-591.

https://www.banglajol.info/index.php/JBAU/article/view/44629

[21] Alam, M.M., Kabir, W. and Khan, I.N. (2008) Booklet on Mechanization-Its Trend and Opportunities in the Agricultural Production System in SAARC Countries. SAARC Agriculture Centre, Bangladesh Agricultural Research Council (BARC), Dhaka.

[22] http://www.brri.gov.bd

[23] http://www.bari.gov.bd

[24] https://fpm.bau.edu.bd/

[25] Hasan, K., Tanaka, T.S., Alam, M., Ali, R. and Saha, C.K. (2020) Impact of Modern Rice Harvesting Practices over Traditional Ones. Reviews in Agricultural Science, 8, 89-108. https://doi.org/10.7831/ras.8.0 89

[26] Zhang, X., Rashid, S., Ahmad, K. and Ahmed, A. (2014) Escalation of Real Wages in Bangladesh: Is It the Beginning of Structural Transformation? World Development, 64, 273-285. https://doi.org/10.1016/j.worlddev.2014.06.015 
[27] MOA (Ministry of Agriculture) (2020). https://moa.gov.bd/

[28] Nath, B.C. and Nam, Yo-So. (2014) Improvement of Paddy Harvesting Mechanization System for Bangladesh. In: KOICA, Harvesting Mechanization of Bangladesh, Korea International Cooperation Agency, Seongnam, 48.

https://www.researchgate.net/publication/332670341 Improvement of Paddy Har vesting Mechanization System for Bangladesh

[29] Alizadeh, M.R. and Allameh, A. (2013) Evaluating Rice Losses in Various Harvesting Practices. International Research Journal of Applied and Basic Sciences, 4, 894-901. https://www.researchgate.net/profile/Alireza-Allameh/publication/267208222 Evaluat ing rice losses in various harvesting practices/links/54477d8c0cf22b3c14e0e100/Ev aluating-rice-losses-in-various-harvesting-practices.pdf

[30] Constable, G. and Somerville, B. (Eds.). (2003) A Century of Innovation: Twenty Engineering Achievements That Transformed Our Lives. Joseph Henry Press, Washington DC. https://trove.nla.gov.au/version/45275264

[31] Morad, M.M. (1995) Optimizing the Rotary Mower Kinematic Parameter for Minimum Mowing Cost. Misr Journal of Agricultural Engineering, 12, 353-363.

[32] Ali, M.R., Hasan, M.K., Saha, C.K., Alam, M.M., Hossain, M.M., Kalita, P.K. and Hansen, A.C. (2018) Role of Mechanical Rice Harvesting in Socio-Economic Development of Bangladesh. 2018 ASABE Annual International Meeting, Detroit, 29 July-1 August 2018, Article ID: 1800751. https://doi.org/10.13031/aim.201800751

[33] Kannan, E., Kumar, P., Vishnu, K. and Abraham, H. (2013) Assessment of Pre and Post-Harvest Losses of Rice and Red Gram in Karnataka. Agricultural Development and Rural Transformation Centre, Institute for Social and Economic Change, Bangalore.

[34] Amponsah, S.K., Addo, A., Dzisi, K.A., Moreira, J. and Ndindeng, S.A. (2017) Performance Evaluation and Field Characterization of the Sifang Mini Rice Combine Harvester. Applied Engineering in Agriculture, 33, 479-489. https://doi.org/10.13031/aea.11876

[35] Islam, S., Rahman, S.M.M., Rahman, M.A., Quasem, M.A., Huda, M.D., Islam, A.K.M.S., et al. (2009) Mechanized Rice Cultivation in Bangladesh: Past Experiences and Future Potentials. AMA, Agricultural Mechanization in Asia, Africa \& Latin America, 40, 36-40.

[36] Fouad, H.A., Tayel, S.A., El-Hadad, Z. and Abdel-Mawla, H. (1990) Performance of Two Different Types of Combines in Harvesting Rice in Egypt. AMA, Agricultural Mechanization in Asia, Africa and Latin America, 21, 17-22.

\section{Supplementary Data}

Supplementary data and information to this article can be found online at (https://www.researchgate.net/publication/332670341_Improvement_of_Paddy_ Harvesting_Mechanization_System_for_Bangladesh) 